\title{
Azalea sawfly Nematus lipovskyi (Hymenoptera: Tenthredinidae), a new invasive species in Europe
}

\author{
JAN MACEK ${ }^{1}$ and PETR ŠÍPEK ${ }^{2}$ \\ ${ }^{1}$ Department of Entomology, National Museum, Kunratice 1, CZ-148 00 Praha 4, Czech Republic; e-mail: macjan@seznam.cz \\ ${ }^{2}$ Department of Zoology, Faculty of Science, Charles University in Prague, CZ-128 42 Praha 2, Czech Republic; \\ e-mail: sipekpetr80@gmail.com
}

Key words. Hymenoptera, Tenthredinidae, Nematus lipovskyi, Czech Republic, Europe, Rhododendron molle, R. luteum, invasive species, morphology, bionomics, dispersal, pest species, horticulture

\begin{abstract}
A new non-native species of sawfly Nematus lipovskyi Smith, 1974, previously known only in the USA, has heavily infested the ornamental azalea plant, Rhododendron molle, in the Czech Republic since at least 2010. The data on this species in the USA is briefly summarized. The larva and hitherto unknown male are newly described and illustrated. The life cycle is described based on field observations and the rearing of larvae collected in Charles University Botanic Garden in Prague. The host plants are listed and include the first record of a European species of azalea (Rhododendron luteum). The current distribution of Nematus lipovskyi in the Czech Republic based on the results of a preliminary monitoring project carried out by Charles University in Prague and the State Phytosanitary Administration is presented. The pathways of its introduction and spread, potential phytosanitary measures and its effect on the environment are briefly discussed.
\end{abstract}

\section{INTRODUCTION}

The recent increase in the number of non-native species of insects being introduced into Europe and their spread, caused by worldwide human travel and trade, has resulted in serious problems throughout Europe, including the Czech Republic. The most well-known examples of invasive species include Cameraria ohridella Deschka \& Dimic, 1986 (Lepidoptera: Gracillariidae) and Harmonia axyridis (Pallas, 1773) (Coleoptera: Coccinellidae), which have had a negative effect on horse chestnut trees and the diversity of local ladybird beetle faunas in the countries invaded, respectively (Percival et al., 2011; Vilcinskas et al., 2013). Recently, the East Asian sawfly Aproceros leucopo$d a$ (Takeuchi, 1939) was introduced into Europe, which resulted in outbreaks of this species and extensive defoliation of elms in some parts of South and Central Europe (Blank et al., 2010; Zandigiacomo et al., 2011; Seljak, 2012). Here we report another non-native species of sawfly that has appeared in Europe, the Azalea sawfly, Nematus lipovskyi Smith, 1974, which locally has become a pest of the ornamental azalea, Rhododendron molle, planted in parks and gardens in certain locations in the Czech Republic.

Nematus lipovskyi is a member of the subfamily Nematinae (Tenthredinidae), a group of sawflies with over 1000 species worldwide, of which about 550 occur in Europe (Taeger et al., 2010; Taeger \& Blank, 2011). The mostly free-feeding larvae are usually monophagous or oligophagous on various trees, herbaceous plants and grasses.

Nematus lipovskyi was described by Smith (1974) from females reared from swamp azalea (Rhododendron molle). The type series consists of specimens from the following US states: Massachusetts, New Jersey, Pennsylvania, Ala- bama, Maryland, Maine, New Hampshire and Virginia. According to some references (Johnson \& Lyon, 1991; Boggs et al., 2000; Cranshaw, 2004) it is apparent that N. lipovskyi is widely distributed in the eastern part of the USA, where it is a familiar pest of ornamental deciduous species of Rhododendron (Azalea), both native (such as $R$. calendulaceum and $R$. viscosum) and introduced ( $R$. molle from China and Japan). In addition to Nematus lipovskyi, there are two other species of sawfly in the USA associated with azalea plants: Amauronematus azaleae Marlatt, 1896 (Tenthredinidae, Nematinae) and Arge azaleae Smith, 1989. Outside the USA there is only a passing reference to an unspecified rhododendron sawfly belonging to the family Argidae in Quanzhou City in China (Zheng \& Chen, 2011), possibly Arge similis (Snellen van Vollenhoven, 1860) (D. Smith, pers. comm.). In the Czech Republic, Nematus lipovskyi was first recorded in 2010 based on larvae extensively defoliating Rhododendron molle in Charles University Botanic Garden in Prague. Due to a failure to rear the species, it was not reliably identified until 2013 when females were collected directly from rhododendron shrubs. In spite of the larvae being relatively well-known, they have not previously been described and the males are unknown. Therefore, both larvae and males are described here. In addition, the current status of this species' occurrence in the Czech Republic based on the preliminary results of a preliminary monitoring project carried out by the Charles University Faculty of Science and the State Phytosanitary Administration (hereafter abbreviated as SPA) (Kapitola \& Pekárková, 2013), is also presented. Furthermore, an account of the bionomics of the local population of $N$. lipovskyi in Charles University Botanic Garden, based on field observations is also presented. 

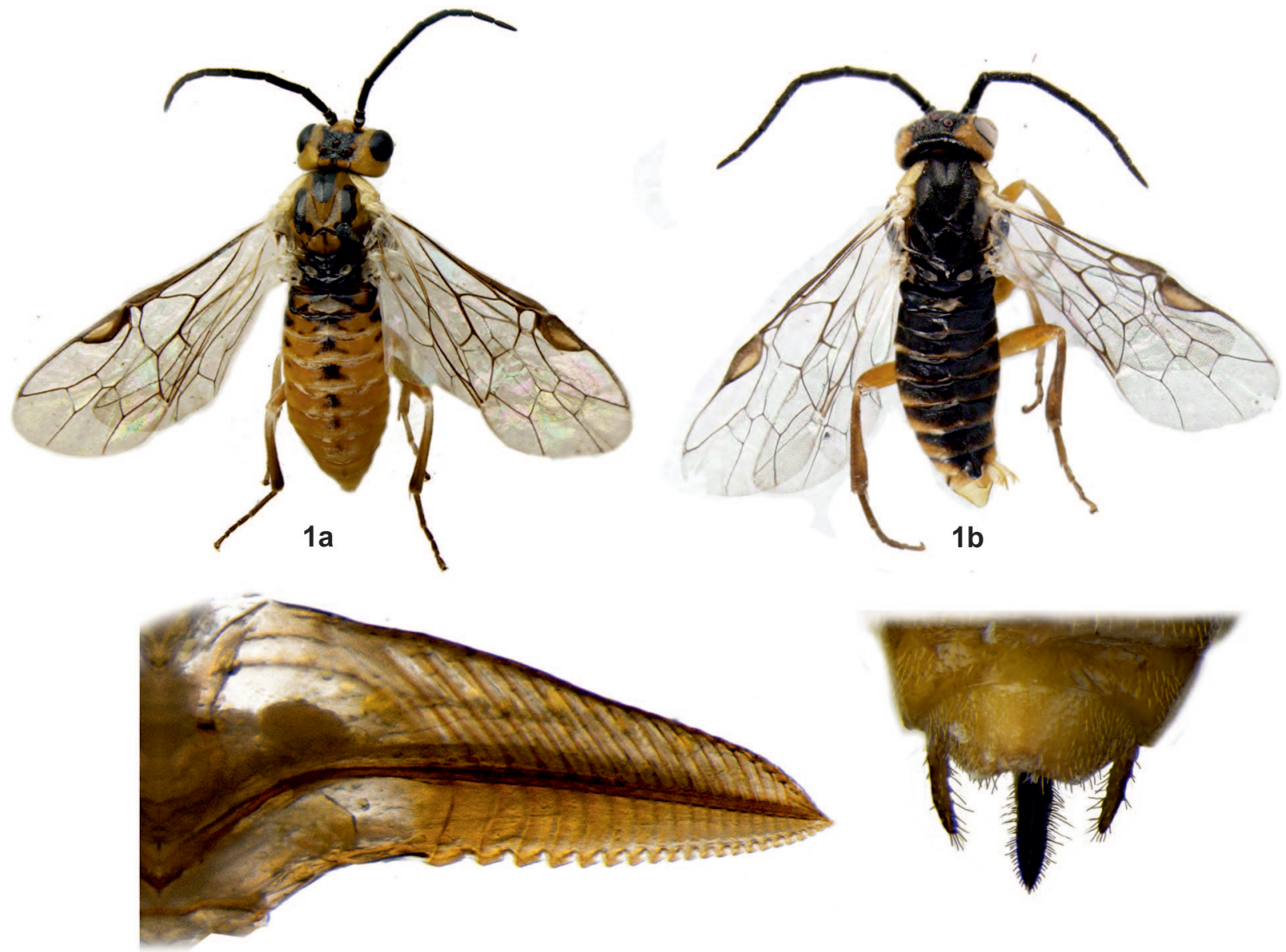

1c

$1 d$
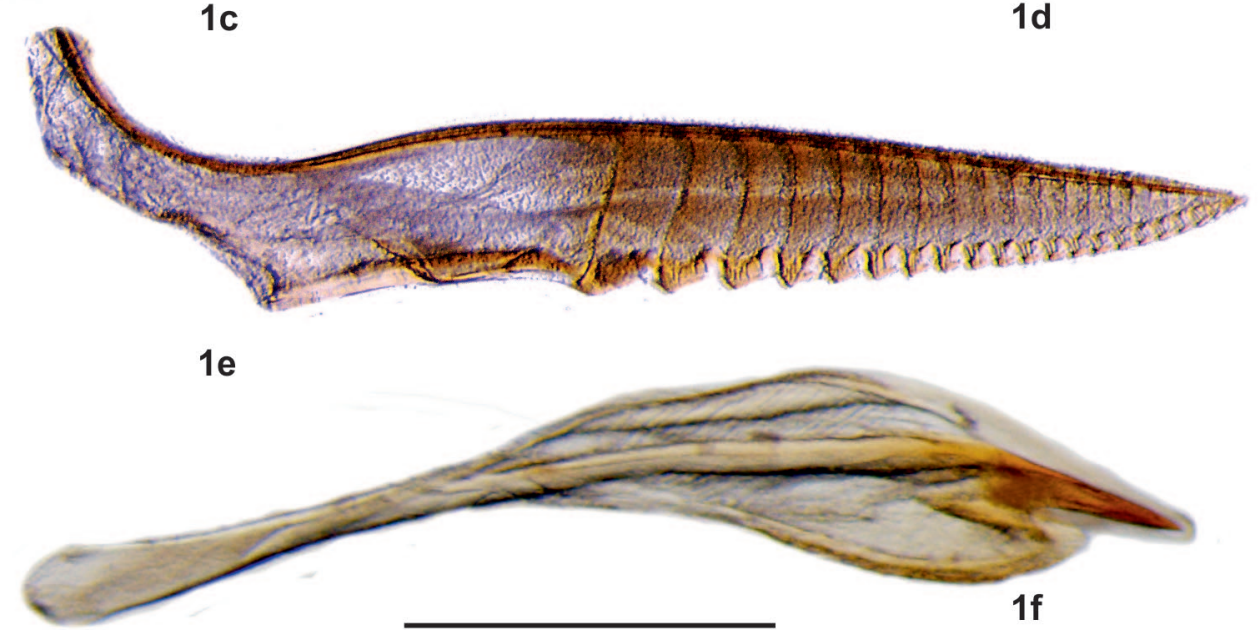

Fig. 1. Nematus lipovskyi Smith, 1974, adult: a - female; b - male; c-ovipositor (lateral view); d - female abdomen (apical part, dorsal view); e - lancet; $\mathrm{f}$ - penis valva. Scales: $\mathrm{a}, \mathrm{b}-5 \mathrm{~mm}$; , e, $\mathrm{f}-0.3 \mathrm{~mm} ; \mathrm{d}-12 \mathrm{~mm}$.

\section{MATERIAL AND METHODS}

Samples of both adults and larvae (approx. 200 adults and 300 larvae) were collected from Charles University Botanic Garden by one of the authors (PŠ), other samples of larvae were collected at various locations throughout the Czech Republic by SPA inspectors (Kapitola \& Pekárková, 2013). All material was submitted for identification to the Entomological Department of the National Museum in Prague. Distribution records are supplemented with the respective faunistic grid number of the grid mapping system of Central Europe (Ehrendorfer \& Hamann, 1965; Pruner \& Míka, 1996). Taxonomic analysis was carried out using standard entomological procedures for morphological diagnostics. This species was identified based on Smith's (1974) original description. Field observations on the occurrence, oviposition behaviour and level of damage caused by N. lipovskyi in Charles University Botanic Garden were carried out by P. Šípek, who also took photographs of living specimens and the damage to the host plants. Voucher specimens of both larvae and adults are deposited in the insect collection at the Department of Entomology, National Museum, Prague; photographs are kept in Charles University Faculty of Science photograph gallery archive. The distribution map (Fig. 4) was prepared from a draft map produced by SPA and vector maps were downloaded from http:/www.vecteezy.com/. For light microscopy of the collected material (Figs 1-2) a series 


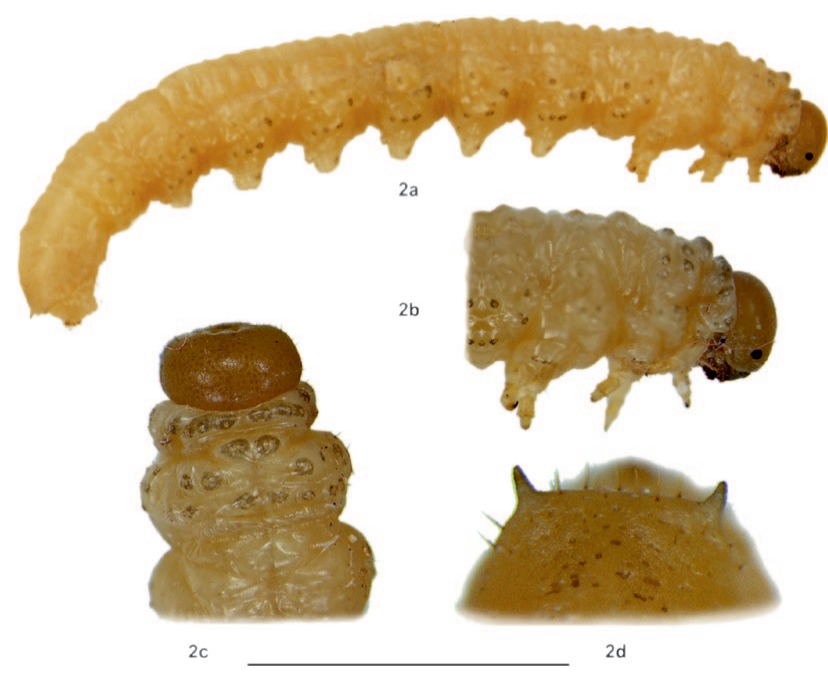

Fig. 2. Nematus lipovskyi Smith, 1974, last feeding larval instar preserved in alcohol (discolored): a - habitus (lateral view); $\mathrm{b}-$ head + thorax (lateral view); $\mathrm{c}-$ head + thorax (dorsal view); $\mathrm{d}$ - anal segment with caudal protuberances (dorsal view). Scales: $\mathrm{a}-5 \mathrm{~mm}$; b, c- $4 \mathrm{~mm} ; \mathrm{d}-1 \mathrm{~mm}$

of digital photographs was taken with an OLYMPUS DP camera attached to an OLYMPUS SZX microscope. Composite images with an extended depth of focus were created using the software CombineZP and subsequently processed using other graphic programmes. The other images were taken with various standard cameras. Morphological terminology used in the descriptions follows that of Viitasaari (2002).

\section{RESULTS}

\section{Nematus lipovskyi Smith, 1974}

Description. Adult. Female (Fig. 1) was described by Smith (1974) who also provided illustrations of the ovipositor sheath and lancet.

Male (Fig. 1): Length: 4.5-5 mm. Yellow-orange with antennae, large spot on frontal field (extending as far as frontal pit and antennal socket), mesonotum and metanotum, dorsal and ventral part of mesopleuron, metapleuron, proximal half of metacoxa, all terga except narrow stripes on posterior margins and laterotergites, black.

Head. Alutaceous, with short, dense, pale pubescence; in dorsal view transverse with temples parallel and rounded posteriorly; postocellar area slightly convex, twice as wide as long, lateral postocellar furrows short, slightly depressed, parallel; OOL : OOC : $\mathrm{POL}=1: 1: 0.9$; frontal field flat with indistinct frontal ridge; frontal pit deep, narrowly triangular; clypeus flat, shiny, with deeply emarginate anterior margin; malar space as long as diameter of anterior ocellus; antenna distinctly longer than head and thorax combined; relative lengths of flagellomeres 3-9 about $0.95: 1: 1: 0.75: 0.70: 0.63: 0.63$.

Thorax. Median mesoscutal lobe shiny in middle with shallow scattered punctures, alutaceous anteriorly; median mesoscutellar groove arc-shaped and narrow; lateral mesoscutal lobes covered with dense shallow punctures with alutaceous interspaces; mesoscutellum slightly convex, shiny, with fine sparse punctures; mesopleuron with dense fine punctures; mesoscutellar appendage with distinct, deep punctures; metascutellum smooth, shiny; legs with metatarsus a little shorter than metatibia, metabasitarsus as long as three following tarsomeres combined; inner tibial spur of metatibia a little shorter than half of metabasitarsus, claws with small inner tooth.

Abdomen. Cylindrical with apex rounded posteriorly, terga finely alutaceous, sterna shiny with scattered punctation; genitalia as in Fig. 1.

Variability. No significant variation in the material available.

Last-instar feeding larva (Figs 2, 3c). Body length 9-10 mm. Head greyish-green; entire head covered with scattered fine homogeneous pubescence; clypeus with four setae, labrum with four setae; mandibles with one seta, stipes without setae, palpifer with three setae; second segment of maxillary palps with one small seta; prementum with two very short setae, second segment of labial palp with one short seta; body in upper part green, in lower part paler; cuticle smooth and shiny, spiracles narrow; all thoracic segments with a pair of large dorsal lobes with long setae, trochanter shorter than femur, with scattered long hair-like setae, tibia longer than tarsus with ten hair-like setae; abdominal segments with six annulets, annulets three, five and six very narrow, strip-like, tightly associated with preceding annulet; first, second and fourth annuli large, convex dorsally; subspiracular, second postspiracular and surpedal lobes prominent with ring-like spots surrounding setal bases; second annulet with six, fourth annulet with eight long hair-like setae; first postspiracular lobe with one, second postspiracular lobe with two long cylindrical setae, ninth abdominal segment with two short conical protuberances, suranal and subanal lobes with long hair-like setae, basal parts of prolegs with black spots, covered with scattered long hair-like setae.*

Bionomics. This species is univoltine. Adults were observed from the end of April to the beginning of May 2013, with a peak between 22-24 April. However the flight period might be influenced by temperature and may be prolonged from mid-April to mid-May. The temperatures during peak flight days were as follows: minimum temperature $5^{\circ} \mathrm{C}$, maximum day temperature $22^{\circ} \mathrm{C}$, mean temperature $13.2^{\circ} \mathrm{C}$ (Anonymous, 2014). The main flight period coincided with the bursting of the floral buds of the host plants. During the flight period mass swarming was observed, with several hundreds of females flying around the bushes. The flying individuals were not attracted to yellow pitfall traps (on the ground) or yellow sticky plates in the branches. Surprisingly, no males were caught in flight, but some 10 male individuals were collected attached to the sticky covers of $R$. obtusum buds a few days later. During the flight period, females were observed laying eggs in the central vein of young leaves in bursting buds (Fig. 3). Oviposition was preceded by thorough inspection of the bud. Young larvae hatched within 7-10 days of ovi-

* The habitus of the last feeding larval instar differs significantly from the preceding instars, which are characterized by the presence of prominent black setiferous pinnacles on the dorsal parts of thorax and abdomen. 

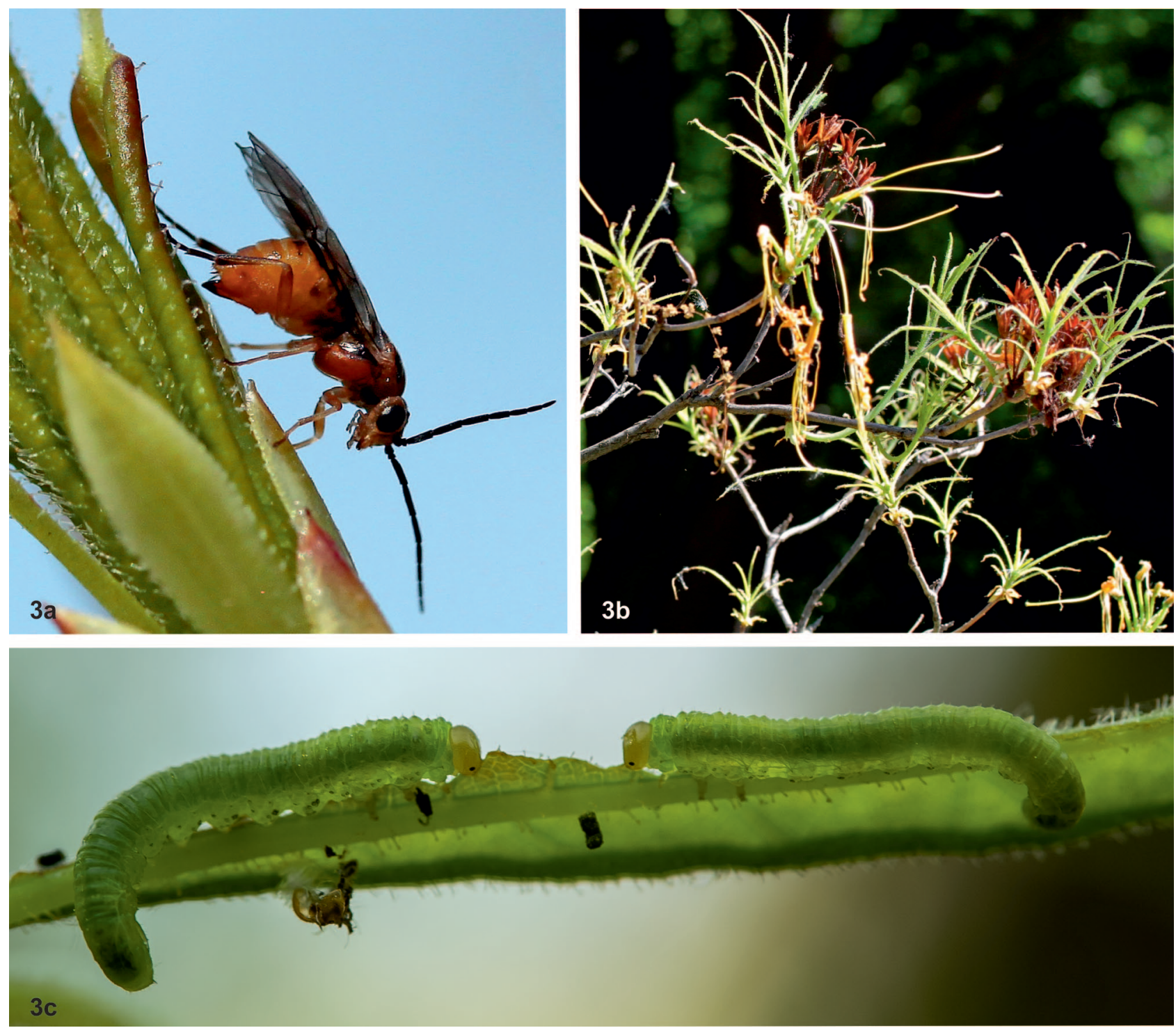

Fig. 3. Nematus lipovskyi Smith, 1974: a - ovipositing female; b - damage to R. luteum; $\mathrm{c}$ - alive larvae feeding on R. luteum (lateral view).

position. The feeding tracks on the leaves have a characteristic appearance. Larvae of the last feeding instar were recorded from mid-May to the end of May. Larvae start feeding on the leaf margin and subsequently completely consume the whole leaf except for the thick central vein. The first visible damage occurs approximately two weeks after oviposition and if there is a severe infestation the host plants are completely defoliated within two to three weeks of larval emergence (Fig. 3). The final non-feeding larval instar (eonymph) descends and burrows into the soil where it hibernates as a prepupa inside a firm cocoon. Pupation occurs after hibernation and depending on the temperature adults emerge between mid-April and mid-May.

In the USA, Smith (1974) listed Rhododendron viscosum and $R$. molle as food plants; Johnson \& Lyon (1991) added $R$. calendulaceum. In the Czech Republic, in addition to $R$. molle two other species of Rhododendron were recorded as host plants for $N$. lipovskyi, the European $R$. luteum Sweet and the $R$. obtusum hybrid "Ledikanense" from Japan. Host plants, their origin and the parts consumed are listed in Table 1. Larvae fed on both the leaves and blossoms of $R$. molle and $R$. luteum. Only the flowers of $R$. obtusum were consumed, suggesting that $R$. obtusum may only be an accidental host plant.

Distribution. This species was first collected in 1924 in Massachusetts, USA, but it was not until 1974 that it was formally described by Smith (1974). The USA is so far the only country in which $N$. lipovskyi naturally occurs and is distributed there in the eastern states from Maine in the north to Alabama in the south; unverified records exist for Wisconsin (Fig. 4) (D. Smith, pers. comm.). In Europe, it was first recorded in 2010 in the Charles University Botanic Garden, Prague (Czech Republic) based on larvae feeding on Rhododendron molle and R. luteum. Flying adults were not recorded there until 2013. Additional data were obtained either by inspectors of the SPA and other public services during 2013 (Kapitola \& Pekárková, 2013) or came from various gardening enthusiasts (Fig. 4). Reports from private gardening enthusiasts were only taken into account if they were sufficiently reliable (e.g. with a pho- 


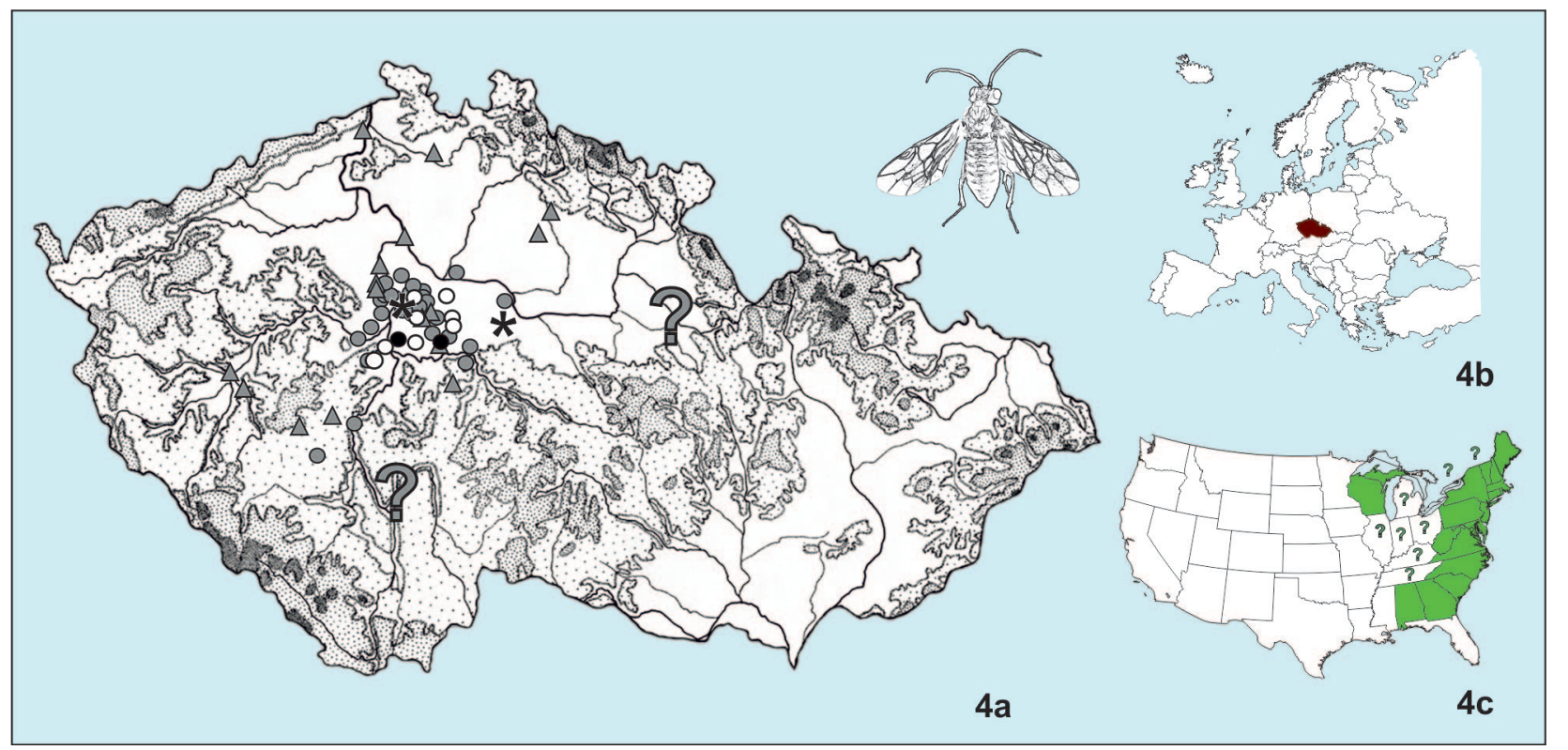

Fig. 4. Distribution of N. lipovskyi in the United States and the Czech Republic. Asterisk - records since 2010; full circles - records since 2011; open circles - records since 2012; grey circles - records since 2013; grey triangles - records since 2013 (SPA data).

tograph), but did provide feedback on how long the species had been causing visible damage in a particular locality. All records were confined to Bohemia, most were for Central Bohemia (34) and Prague (18), but the species was also recorded in the regions of Hradec Králové (2), Plzeň (2), Pardubice (1), Liberec (1), Ústí (1) and South Bohemia (2). Except for the above mentioned records of adults in the Botanic Garden, all records are based exclusively on finding larvae and feeding tracks on food plants. This species appears to disperse relatively slowly; with only two records of $N$. lipovskyi in 2010, an additional two in 2011 and nine new localities in 2012. Currently the species is recorded in at least 60 localities.

\section{Distribution records}

Records since 2010: Bohemia centr., Praha, Botanic Garden of the Faculty of Science, Charles University in Prague, Prague. 190 m a.s.l. Pavlata J., Macek P. \& Šípek lgt. (5952); Bohemia centr, Kořenice near Kolín, 323 m a.s.1., Hoblová, pers. comm. (6059); Records since 2011: Bohemia centr., Vrané nad Vltavou, 196 m a.s.l., Tejnická, pers. com. (6052); Bohemia centr., Senohraby, 363 m a.s.l., Tóbiková, pers. com. (6164). Records since 2012: Bohemia centr., Praha 8, D́áblice, 263 m a.s.l., Malá, pers. com. (5852); Bohemia centr., Újezd nad Lesy, $255 \mathrm{~m}$ a.s.l., Carvanová, pers. com. (5953); Bohemia centr., Průhonice, 306 m a.s.1., Gabrielová, pers. com. (5953, 6053); Bohemia centr.,
Březí, 330 m a.s.1., Opplová, pers. com. (5954); Bohemia centr., Dobřichovice, $205 \mathrm{~m}$ a.s.l., Rundová, pers. com. (6051); Bohemia centr., Okrouhlo, Zahořany village, 275 m a.s.l., Liška, pers. com. (6052); Bohemia centr., Mukařov, 427 m a.s.l., Hradecká, pers. com. (6054); Bohemia centr., Mníšek pod Brdy, 385 m a.s.1., Hančilová, pers. com. (6151); Bohemia centr., Štěchovice, 215 m a.s.l., Jeřábková, pers. com. (6152). Records since 2013: Bohemia bor., Děčín, 135 m a.s.l. (Kapitola \& Pekárková, 2013) (5250, 5251); Bohemia bor., Česká Lípa, 258 m a.s.l. (Kapitola \& Pekárková 2013) (5353); Bohemia or., Jičín, 284 m a.s.l. (Kapitola \& Pekárková, 2013), (5558); Bohemia centr., Mělník, 215 m a.s.l. (Kapitola \& Pekárková, 2013) (5652, 5653); Bohemia or., Kopidlno, 219 m a.s.l. (Kapitola \& Pekárková, 2013) (5657); Bohemia centr., Dolany u Prahy, $192 \mathrm{~m}$ a.s.l. (Kapitola \& Pekárková, 2013) (5752); Bohemia centr., Statenice, 258 m a.s.l. (Kapitola \& Pekárková, 2013) (5851); Bohemia centr., Svrkyně, 295 m a.s.l. (Kapitola \& Pekárková, 2013) (5851); Bohemia centr., Praha 8, 263 m a.s.l., Jurášková, pers. com. (5852); Bohemia centr., Roztoky u Prahy, 237 m a.s.l., Vlčková, pers. com. (5852); Bohemia centr., Zdiby u Prahy, 295 m a.s.l., Seidl, pers. com. (5852); Bohemia centr., Husinec u Řeže, 180 m a.s.l. (Kapitola \& Pekárková, 2013) (5852); Bohemia centr., Praha 7 - Stromovka, 190 m a.s.l., Vodváŕka, pers. com. (5852, 5952); Bohemia centr., Praha - Vinoř, 247 m a.s.l., Řeháková, pers. com. (5853); Bohemia centr., Praha 9, Vysočany, 201 m a.s.1., Král, pers. com. (5853, 5952, 5953); Bohemia centr., Káraný, 173 m a.s.l., Lohrová, pers. com. (5854); Bohemia centr., Velký Osek

TABLE 1. Host plants of N. lipovskyi.

\begin{tabular}{lccc}
\hline Host plant species & $\begin{array}{c}\text { Country of origin of host plant / } \\
\text { observation of infestation }\end{array}$ & Consumed parts & Source \\
\hline $\begin{array}{l}\text { Rhododendron molle (Blume) G. Don } \\
\text { and hybrids }\end{array}$ & China, Japan / USA, Czech Rep. & Leaves, flowers & Smith, 1974; pers. observ. \\
$\begin{array}{l}\text { Rhododendron calendulaceum } \text { (Michx.) Torr. } \\
\text { Rhododendron viscosum (L.) Torr. }\end{array}$ & USA / USA & $\begin{array}{c}\text { Leaves, flowers (?) } \\
\text { Leaves, flowers (?) }\end{array}$ & Smith, 1974 \\
Rhododendron luteum Sweet & USA / USA & East and Central Europe, \\
Rhododendron $\times$ obtusum "Ledikanense" & West Asia / Czech Rep. & Leaves, flowers & Pers. observ. \\
\hline
\end{tabular}


- Oseček, 191 m a.s.1., Koubová, pers. com. (5856); Bohemia centr., Praha 4, Bráník, 199 m a.s.l., Votýpka, pers. com. (5952); Bohemia centr., Praha 6, Břevnov, $320 \mathrm{~m}$ a.s.l., Svoboda, pers. com. (5952); Bohemia centr., Praha 6, Střešovice, 274 m a.s.1., Buriánek, pers. com. (5952); Bohemia centr., Praha 6, Ruzyně, 274 m a.s.l., Vinkler, pers. com. (5952); Bohemia centr., Praha 5, Smíchov, 196 m a.s.l., Havová, pers. com. (5952); Bohemia centr., Praha 4, Krč, 225 m a.s.l., Němcová, pers. com. (5952); Bohemia centr., Praha 10, Štěrboholy, 285 m a.s.l., Foltýn, pers. com. (5953); Bohemia centr., Praha 9, Počernice, 227 m a.s.l., Veber, pers. com. (5953); Bohemia centr., Praha, Uhř́iněves, 277 m a.s.l., Anderlová, pers. com. (5953); Bohemia centr., Praha, Křeslice, 282 m a.s.l., Fiala, pers. com. (5953); Bohemia centr., Pacov u Ř́čan, 346 m a.s.l., Vojáčková, pers. com. (5954); Bohemia or., Choceň, 290 m a.s.l., Pavco, pers. com. (5963, 6063) (doubtful record); Bohemia centr., Třebotov, 350 m a.s.l., Bašta, pers. com. (6051); Bohemia centr., Praha, Radotín, 202 m a.s.l., Černý, pers. com. (6052); Bohemia centr., Ríčany, 341 m a.s.l., Macháčková, pers. com. (6053, 6054); Bohemia centr., Kamenice, 368 m a.s.l., Šefrna. pers. com. (6053, 6153); Bohemia centr., Jevany, 380 m a.s.l., (Kapitola \& Pekárková, 2013) (6054); Bohemia centr., Čakovice, 320 m a.s.l., (Kapitola \& Pekárková, 2013) (6153); Bohemia centr., Samechov, 383 m a.s.l., Vávrová, pers. com. (6155); Bohemia occ., Plzeň, 300 m a.s.l., (Kapitola \& Pekárková, 2013) (6245, 6246); Bohemia centr., Lhotka u Dobř́íse, 387 m a.s.l., (Kapitola \& Pekárková, 2013) (6250); Bohemia centr., Benešov u Prahy, 360 m a.s.1., (Kapitola \& Pekárková, 2013) (6254); Bohemia occ., Št’áhlavy, 362 m a.s.l., (Kapitola \& Pekárková, 2013) (6346, 6347); Bohemia centr., Rožmitál pod Třemšínem, 519 m a.s.l., (Kapitola \& Pekárková, 2013) (6349); Bohemia centr., Kamýk nad Vltavou, 274 m a.s.l., Večeřová, pers. com. (6351); Bohemia mer., Blatná, 440 m a.s.l., Šípek lgt. (6549); Bohemia mer., Olešná, 426 m a.s.l., anonymous, pers. com (6651) (unverified record).

\section{DISCUSSION}

Based on the known distribution of $N$. lipovskyi it would be easy to assume that the species was introduced into the Czech Republic from the USA with ornamental azalea plants used in horticulture. However this assumption may not be justified, as the fact that $N$. lipovskyi was originally detected in the USA may not mean that the species originated from there. In fact, there are several species of sawfly described from their secondary populations outside their native ranges. For example, Nematus tibialis Newman, 1837 feeding on false acacia (Robinia pseudoacacia Linnaeus, 1753), which is native to North America, was described from Europe (Smith, 1979); another example is Pristiphora angulata Lindqvist, 1974 described from Scandinavia. The larvae of this species are known to develop on a non-native Spiraea species, indicating that the species must have originated elsewhere (Lindqvist, 1974). Revealing the origin of $N$. lipovskyi would involve intensive field research in all areas where soft-leaved azaleas occur, as well as revising all the known species of Nematus to eliminate possible synonymies.

The newly established population of $N$. lipovskyi in the Botanical Garden in Prague consumed not only $R$. molle, but also caused considerable damage to $R$. luteum and inflorescences of $R$. obtusum. Rhododendron luteum, therefore, is a new food plant for Nematus lipovskyi. R. luteum is native to southeast Europe and southwest Asia. In Eu- rope it occurs in neighbouring countries such as Poland and Austria south through the Balkans and east to southern Russia (Anisko \& Czekalski, 1993; Resner, 2005; Rencová, 2013). In Britain, as an invasive plant species, it has colonised many wet peatlands and bogs (Pilkington, 2011), whereas the Austrian and Polish populations are protected (Rencová, 2013). Whether N. lipovskyi presents a potential risk to the native population of soft-leaved deciduous rhododendrons, or whether it can be used to control this species is unknown and needs to be tested. However, our observations suggest that a mass occurrence of azalea sawflies can lead to complete defoliation, which prevents the plant from reproducing. Moreover, after 3 successive years of defoliation plants are visibly weaker and partial dieback occurrs. In the USA, no large outbreaks followed by continuous defoliation of azalea plants are reported (D. Smith, unpubl. data; Johnson \& Lyon, 1991).

The present results based mostly on feeding tracks and larval samples suggest Prague and its eastern outskirts to be the very epicentre of this invasive species as the majority of samples are recorded from this region. The most remote records are from Děčín (North Bohemia), and Plzeň (West Bohemia). N. lipovskyi is univoltine with a limited flight period, therefore we consider the dispersal potential of adults to be rather low or local. It is presumed that the primary agents of spread of this species might be young plants carrying eggs and soil containing cocoons. On the other hand a congeneric willow-feeding species $N$. oligospilus (Förster, 1854) dispersed remarkably quickly when introduced into the southern hemisphere (Urban \& Eardley, 1995; Koch \& Smith, 2000; Caron et al., 2013), therefore the dispersal and distribution of this species across Europe should be monitored.

ACKNOWLEDGEMENTS. We are grateful to D. Smith (USA) for providing general information on the distribution and biology of the azalea sawfly in the USA and for valuable comments on the manuscript. C. Carrington (Prague, Czech Republic) kindly proofread the English. We would also like to thank L. Pavlata (Charles University Botanic Garden in Prague) for his help with this investigation. T. Rủžička and P. Kapitola, both members of the State Phytosanitary Administration (which is currently a section of the Central Institute for Supervision and Testing in Agriculture), kindly provided the data on the distribution of $N$. lipovskyi collected by the SPA. This work was financially supported by Ministry of Culture of the Czech Republic (DKRVO 2014/12, National Museum, 00023272).

\section{REFERENCES}

Anisko T. \& Czekalski M. 1993: Pontic azalea in Poland. - $J$. Am. Rhododendron Soc. 47: 189-191.

Anonymous 2014: Weather Records for Prague. Available: http:// pocasi.divoch.cz/praha.php?fd=2013-04-22. Accessed on 22 January 2014.

Blank S.M., Hara H., Mikulás J., Csóka G., Ciornei C., Constantineanu R., Constantineanu I., Roller L., AltenhoFER E., Huflejt T. \& VéteK G. 2010: Aproceros leucopoda (Hymenoptera: Argidae): An East Asian pest of elms (Ulmus spp.) invading Europe. - Eur. J. Entomol. 107: 357-367.

Boggs J.F., Young C.E., Shetlar D.J., Draper E.A., Gao G.Y., Chatfield J.A., Martin J.C. \& Bennett P.J. 2000: Insect and 
Mite Activity Noted in Ohio Nurseries and Landscapes: Ornamentals Plants Annual Reports and Research Reviews 2000. Special Circular 177-01. Ohio Agricultural Research and Development Center, The Ohio State University, Columbus, pp. 29-40.

Caron V., Ede F., Sunnucks P. \& O’Dowd D.J. 2014: Distribution and rapid range expansion of the introduced willow sawfly $\mathrm{Ne}$ matus oligospilus Förster in Australasia. - Austral. Entomol. 53: $175-182$.

Cranshaw W. 2004: Garden Insects of North America: The Ultimate Guide to Backyard Bugs. Princeton University Press, Princeton, NJ, $672 \mathrm{pp}$.

EHRENDORFER F. \& HAMANN U. 1965: Vorschläge zur einer floristischen Kartierung von Mitteleuropa. - Ber. Dtsch. Bot. Ges. 78: $35-50$.

Johnson W.T. \& Lyon H.H. 1991: Insects that Feed on Trees and Shrubs. 2nd ed. Cornell University Press, Ithaca, NY, 560 pp.

Kapitola P. \& PeKáRková J. 2013: Sawfly Nematus lipovskyi (Hymenoptera: Tenthredinididae). Pest Risk Analysis, version 1, December 2013. 16 pp. Available: http://eagri.cz/public/ web/ukzuz/portal/skodlive-organismy/an-rizik/analyzy-rizikv-cr/. Accessed 28 February 2014 [in Czech].

Kосн F. \& Sмітн D.R. 2000: Nematus oligospilus Förster (Hymenoptera: Tenthredinidae), an introduced willow sawfly in the Southern Hemisphere. — Proc. Entomol. Soc. Wash. 102 292-300.

LindQvist E. 1974: Taxonomische Bemerkungen über einige Blattwespen II (Hymenoptera, Symphyta). - Notulae Entomol. 54: 17-22.

Percival G.C., Barrow I., Novissa K., Keary I. \& Pennington P. 2011: The impact of horse chestnut leaf miner (Cameraria ohridella Deschka and Dimić) on vitality, growth and reproduction of Aesculus hippocastanum L. - Urban Forest. Urban Green. 10: 11-17.

Pilkington S. 2011: Rhododendron luteum. GB Non-natives Factsheet Editor. Available at: http://www.brc.ac.uk/gbnn admin/index.php?q=node/283. Accessed 3 December 2013.

Pruner L. \& Míka P. 1996: List of settlements in the Czech Republic with associated map field codes for faunistic grid mapping system. — Klapalekiana (Suppl.) 32: 175 pp. [in Czech].
RencovÁ E. 2013: Rhododendron luteum Sweet. Botany.cz, 2007-2012. Available at: http://botany.cz/cs/rhododendronluteum. Accessed 3 December 2013 [in Czech].

RESNER V. 2005: The Rhododendron species of Europe. - Živa 2005(4): 157-158 [in Czech].

SelJAK G. 2012: Six new alien phytophagous insect species recorded in Slovenia in 2011. - Acta Entomol. Slovenica 20: $31-44$.

Sмiтh D.R. 1974: Azalea sawflies and a new species of Nematus Panzer (Hymenoptera: Symphyta). - Proc. Entomol. Soc. Wash. 76: 204-207.

SмIтH D.R. 1979: Suborder Symphyta. In Krombein K.V., Hurd P.D. Jr., Smith D.R. \& Burks B.D. (eds): Catalog of Hymenoptera in America North of Mexico. Vol. 1, Symphyta and Apocrita (Parasitica). Smithsonian Institution Press, Washington D.C., pp. 3-137.

TAEger A. \& Blank S.M. 2011: ECatSym - Electronic World Catalog of Symphyta (Insecta, Hymenoptera). Program version 3.9, data version 38 (07.12.2011). Digital Entomological Information, Müncheberg. Available at: http://www.sdei.de/ ecatsym/ecatsym.php. Accessed on 3 December 2013.

Taeger A., Blank S.M. \& Liston A.D. 2010: World catalog of Symphyta (Hymenoptera). - Zootaxa 2580: 1-1064.

URBAN A.J. \& EARDLEY C.D. 1995: A recently introduced sawfly, Nematus oligospilus Forster (Hymenoptera: Tenthredinidae), that defoliates willows in southern Africa. - Afr. Entomol. 3: 23-27.

VittasaARi M. 2002: The suborder Symphyta of the Hymenoptera. In Viitasaari M. (ed.): Sawflies I. Tremex Press, Helsinki, pp. 11-149.

Vilcinskas A., Stoecker K., Schmidtberg H., Röhrich C.R. \& Vogel H. 2013: Invasive harlequin ladybird carries biological weapons against native competitors. - Science 34: 862-863.

Zandigiacomo P., Cargnus E. \& Villani A. 2011: First record of the invasive sawfly Aproceros leucopoda infesting elms in Italy. - Bull. Insectol. 64: 145-149.

ZHENG Y. \& CHEN D. 2011: Occurrence investigation and control measures of Rhododendron pests in Quanzhou city. - Fujian Agric. Sci. Tech. 2011(4): 65-67 [in Chinese, English abstr.]

Received August 15, 2014; revised and accepted October 1, 2014 Prepublished online November 11, 2014 